\title{
AN IMMUNOLOGIC BASIS FOR ACQUIRED RESISTANCE TO ORAL ADMINISTRATION OF HOG INTRINSIC FACTOR AND VITAMIN $\mathrm{B}_{12}$ IN PERNICIOUS ANEMIA*
}

\author{
By LOUIS LOWENSTEIN, BERNARD A. COOPER, LAUDER BRUNTON AND \\ SUSAN GARTHA WITH THE TECHNICAL ASSISTANCE OF KATALIN KERNER \\ (From the Haematology Service of the Department of Medicine, Royal Victoria Hospital, \\ and the McGill University Clinic, Montreal, Canada)
}

(Submitted for publication August 4, 1960 ; accepted May 12, 1961)

In pernicious anemia, vitamin $B_{12}$ deficiency develops owing to the failure of gastric intrinsicfactor secretion. Patients with this disease absorb vitamin $B_{12}$ from the gastrointestinal tract when it is fed together with an extract of hog pyloric mucosa. Some patients have relapsed during the course of oral therapy with this mixture (1-3). These subjects absorb vitamin $B_{12}$ administered with normal human gastric juice but do not absorb it when it is administered with hog preparations possessing intrinsic-factor activity (3). These patients have become refractory to the hog preparations. It has been reported that sera obtained from most of these refractory patients (4), and from a minority of nonrefractory patients and normal subjects $(5,6)$, possess intrinsic factor-neutralizing properties.

Such observations have directed attention to a possible immunologic mechanism for the refractory state. This study was undertaken to determine whether the refractory state might be due to antibodies against the hog intrinsic-factor preparation, which could be detected in vitro.

\section{METHODS AND MATERIALS}

The standard hog pyloric mucosal extract ${ }^{1}$ (hog IF) was active in the Schilling test at a dosage of $100 \mathrm{mg}$.

Normal human gastric juice was obtained from at least 4 donors after histamine stimulation. After filtration through cheesecloth the juice was adjusted to $\mathrm{pH} 10.0$ with $2 \mathrm{~N}$ sodium hydroxide for 20 minutes to inactivate pepsin (7), neutralized to $\mathrm{pH} 7.0$ to 8.0 with $2 \mathrm{~N}$ hydrochloric acid, and stored at $-20^{\circ} \mathrm{C}$.

To determine whether intrinsic factor could be bound by diazonium groups, fixed diazonium groups were prepared by exposing a column of polyaminopolystyrene to

* Supported by Grant M.A. 802 of the National Research Council of Canada, and by Abbott Laboratories.

1 Ayerst 5310 defatted, desiccated hog pyloric mucosa, generously supplied by Ayerst McKenna \& Harrison Ltd., Montreal. nitrous acid, as described by Gyenes, Rose and Sehon (8). After one or more passages through this column, hog pyloric extract was tested for intrinsic-factor activity in vivo by the Schilling test.

Serum was tested for antibodies by the technique of Stavitsky and Arquilla (9), which uses bis-diazotized benzidine to coat rabbit erythrocytes with antigen. Agglutination of these coated erythrocytes by dilutions of serum was considered to be due to antibodies' combining with the hog proteins bound to the erythrocytes. The specificity of the antibodies was determined by absorbing the serum with hog pyloric extracts, or with nonpyloric hog protein before addition of the coated erythrocytes. Specific agglutination of the coated erythrocytes was defined as agglutination which could be prevented by absorption of the antiserum with hog pyloric mucosal extracts.

To coat the erythrocytes, bis-diazotized benzidine solution $^{2}$ was mixed with a 10 per cent (wt/vol) aqueous solution of hog IF, in a total volume of $1.5 \mathrm{ml}$. To this was added $1.2 \mathrm{ml}$ of a 25 per cent suspension of washed rabbit erythrocytes in normal saline. The optimal ratio of benzidine to antigen was determined previously by carrying out the procedure with different proportions of these materials. With the reagents described here, approximately $1 \mathrm{ml}$ of antigen and $1 \mathrm{ml}$ of the benzidine solution provided optimal coating of the erythrocytes.

The mixture was incubated at room temperature for 10 minutes, agitated, and centrifuged at about 1,200 G. The cells were washed in $3.5 \mathrm{ml}$ of diluent $(0.15 \mathrm{M}$ phosphate buffer at $\mathrm{pH} 7.3$ containing 1 per cent of heat-inactivated normal rabbit serum) and suspended in $2.5 \mathrm{ml}$ of the diluent.

Antiserum was incubated at $56^{\circ} \mathrm{C}$ for 30 minutes to inactivate complement, and diluted serially in $0.5 \mathrm{ml}$ volume of the diluent. All sera were diluted in triplicate, and $0.05 \mathrm{ml}$ of the coated cells was added to each tube of twb series of dilutions. In one of these series, $0.1 \mathrm{ml}$ of

2 Bis-diazotized benzidine was prepared by slowly adding $5 \mathrm{ml}$ of 8.75 per cent $(\mathrm{wt} / \mathrm{vol})$ sodium nitrite $\left(\mathrm{NaNO}_{2}\right)$ to $0.23 \mathrm{~g}$ benzidine in approximately $10 \mathrm{ml}$ water at $0^{\circ} \mathrm{C}$. Water was added to $50 \mathrm{ml}$. Aliquots were frozen in an alcohol-dry ice mixture, and stored at $-20^{\circ} \mathrm{C} ; 1 \mathrm{ml}$ of this solution diluted in $14 \mathrm{ml}$ of $0.15 \mathrm{M}$ phosphate buffer $(\mathrm{pH}$ 7.3) was used in the coating procedure. 
antigen solution was incubated with each dilution for 15 minutes before adding the coated cells. A control was set up by adding uncoated cells to the third series of dilutions.

The test was read after 5 hours' incubation at room temperature. Hemagglutination was recognized by the pattern of sedimentation of erythrocytes at the bottom of the test tubes. Unagglutinated erythrocytes sedimented in a button or ring, whereas agglutinated cells settled in a homogeneous layer.

After the agglutination pattern was recorded, $0.1 \mathrm{ml}$ of 5 per cent $\mathrm{PVP}^{3}$ in phosphate buffer was added to each tube. The tubes were agitated, incubated, and the pattern of settling again noted. This procedure increased the sensitivity of the test.

Rabbits, mixed as to sex and breed, were immunized by the intravenous injection of $3 \mathrm{mg}$ of the standard hog IF preparation in saline. Injections were carried out twice weekly for 3 months, separated by rest periods of 1 month. After two such periods, the serum was assayed for antibodies.

Vitamin $B_{12}$ absorption from the gastrointestinal tract in man was determined by means of the Schilling test. The dose of $\mathrm{Co}^{58}$-vitamin $\mathrm{B}_{12}{ }^{4}$ administered orally was $0.5 \mu \mathrm{g}$ (specific activity approximately $2 \mu \mathrm{c}$ per $\mu \mathrm{g}$ ) and the "flushing" dose of $1,000 \mu \mathrm{g}$ of nonradioactive vitamin $B_{12}$ was administered intramuscularly 2 hours after the oral dose. Urine collections were made for at least 24 hours, and usually for a second 24-hour period at the beginning of which a second injection of $1,000 \mu \mathrm{g}$ of vitamin $B_{12}$ was given. The collection of urine was checked by determining the 24-hour urinary creatinine excretion. The test described by Schwartz, Lous and Meulengracht (4) for anti-intrinsic factor substances in serum was performed by feeding $15 \mathrm{ml}$ of rabbit serum or $30 \mathrm{ml}$ of human serum to the subject immediately before oral administration of an aqueous mixture of hog IF and $\mathrm{Co}^{58}$-vitamin $\mathrm{B}_{12}$.

To study the electrophoretic mobility 5 of intrinsic factor, $0.25 \mu \mathrm{g}$ of $\mathrm{Co}^{58}$-vitamin $\mathrm{B}_{12}$ and $10 \mathrm{mg}$ of the hog pyloric extract were dialyzed against water at $4^{\circ} \mathrm{C}$ for 24 hours. The dialyzed material was mixed with serum from immunized and nonimmunized rabbits, and electrophoresed on Whatman no. 3 paper by a modification (10) of the technique of Grassmann and Hannig (11). The strips obtained were cut into segments and the radioactivity determined in a well-type scintillation counter. Longitudinal segments of the strips were stained for protein with Amidoschwartz $10 \mathrm{~B}$.

Precipitins were sought by a standard saline precipitin technique, with hog IF to which a small quantity of $\mathrm{Co}^{88}$ vitamin $B_{12}$ had been bound (12). The precipitates were

${ }^{3}$ Polyvinylpyrrolidone, $\mathrm{K}$ value 60 , molecular weight 160,000 , generously supplied by Antara Chemicals Corp., Montreal.

4 Obtained from Merck \& Co., Ltd., Montreal.

${ }^{5}$ Electrophoresis performed through the cooperation of Dr. B. Rose and Dr. E. McGarry, Royal Victoria Hospital, Montreal.
TABLE I

\begin{tabular}{|c|c|c|c|}
\hline \multicolumn{2}{|r|}{$\begin{array}{c}\text { Substance } \\
\text { administered }\end{array}$} & $\begin{array}{l}\text { Passages } \\
\text { through } \\
\text { column }\end{array}$ & $\begin{array}{l}\text { Radioactivity } \\
\text { in urine }\end{array}$ \\
\hline \multirow{5}{*}{\multicolumn{2}{|c|}{$\begin{array}{c}\mathrm{B}_{12} \\
\mathrm{~B}_{12}+\mathrm{IF} \\
\mathrm{B}_{12}+\mathrm{IF} \\
\mathrm{B}_{12}+\mathrm{IF}\end{array}$}} & no. & $\%$ \\
\hline & & 0 & 1.3 \\
\hline & & 0 & 16.2 \\
\hline & & 1 & 5.4 \\
\hline & & 2 & 1.7 \\
\hline
\end{tabular}

washed in 0.85 per cent saline, and radioactivity determined.

\section{OBSERVATIONS}

A solution containing $200 \mathrm{mg}$ of the standard hog IF preparation was passed through the diazotized polyaminopolystyrene column. The intrinsic-factor activity of this preparation was markedly reduced by passage through the column and was completely abolished by a second passage (Table I), thus demonstrating that hog intrinsic factor is bound by diazonium groups.

Rabbit serum studies. Dilutions of sera, obtained from immunized rabbits, agglutinated erythrocytes coated with hog IF (Figure 1). Uncoated erythrocytes, or erythrocytes coated with beef or hog insulin by the same technique, were not agglutinated. The antibody titer was abol-

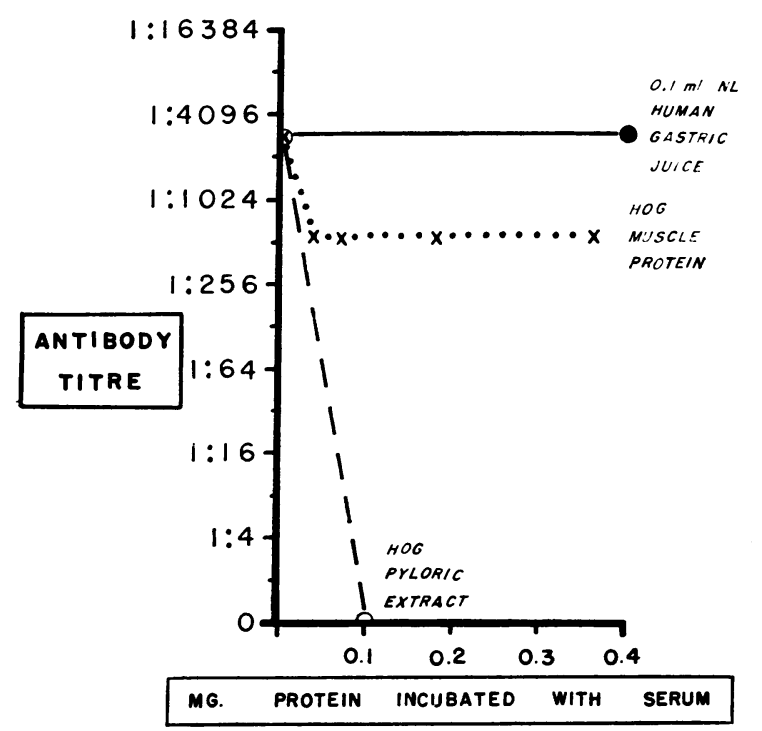

Fig. 1. The effect on the hemagglutination titer OF PRIOR ABSORPTION OF RABBIT ANTISERUM WITH NORMAL HUMAN GASTRIC JUICE, HOG MUSClF FXTRACT, AND HOG IF. 


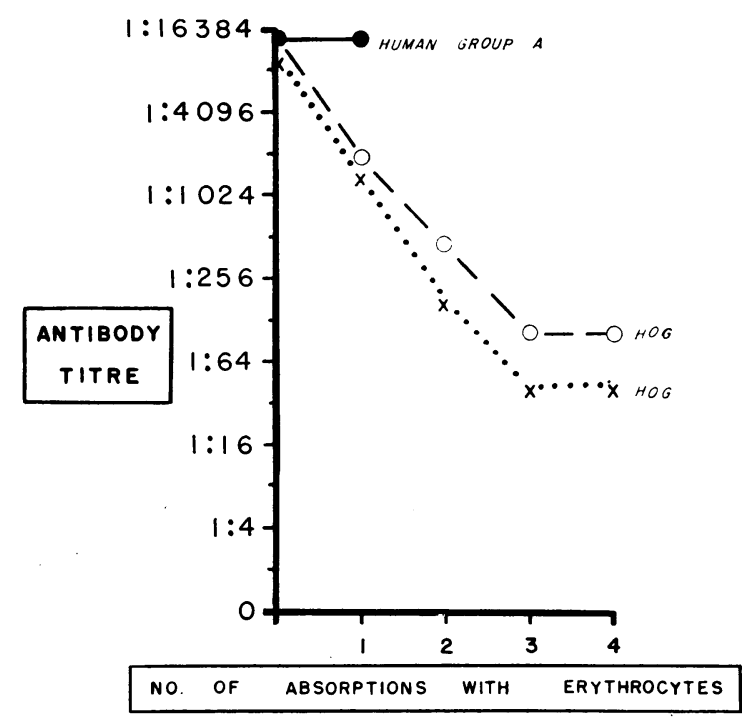

Fig. 2. The efFect on the hemagglutination titer OF PRIOR ABSORPTION OF RABBIT ANTISERUM WITH HOG AND HUMAN ERYTHROCYTES.

ished after incubation of the antiserum with a solution of hog pyloric mucosal extract; it was reduced, but not abolished, after absorption with a soluble extract of hog muscle. Repeated absorptions of the rabbit antiserum with hog erythrocytes reduced but did not abolish the titer (Figure 2). Absorption of antiserum with normal human gastric juice previously dialyzed against water did not alter the titer. In each titration, the coated cells also were exposed to serum from nonimmunized rabbits. These sera did not agglutinate the coated cells. Several hog gastric extracts, ${ }^{6}$ prepared by various techniques such as differential solubility, dialysis, and electrophoresis, were tested for blocking by this technique.

Antiserum absorbed with each of these preparations was exposed to erythrocytes coated with the standard hog IF. The preparations with IF activity, as determined by the Schilling test, completely blocked the agglutination of the coated cells (data not shown). Addition of the hog muscle extract to a potent antiserum reduced the titer from $1: 10,000$ to $1: 640$ (Table II), but subsequent absorption of this antiserum with hog erythrocytes did not further reduce the titer. The

${ }^{6}$ Generously supplied by Dr. F. C. McIntire, Abbott Labs., North Chicago, Ill.; and Dr. L. Ellenbogen, Lederle Labs., Pearl River, N. Y.
TABLE II

Absorption of rabbit antiserum with hog muscle extract, hog erythrocytes, and hog IF; effect on hemagglutination titer

\begin{tabular}{|c|c|c|c|}
\hline \multicolumn{3}{|c|}{ Treatment of antiserum } & \multirow[b]{3}{*}{$\begin{array}{c}\text { Titer } \\
\text { of } \\
\text { serum }\end{array}$} \\
\hline \multicolumn{2}{|c|}{ Addition of } & \multirow{2}{*}{$\begin{array}{l}\text { Absorption } \\
\text { with } \\
\text { hog } \\
\text { RBC's }\end{array}$} & \\
\hline$\underset{\text { IF }}{\text { Hog }}$ & $\underset{\substack{\text { muscle } \\
\text { extract }}}{\text { Hog }}$ & & \\
\hline - & - & - & $1: 10,240$ \\
\hline+ & - & - & 0 \\
\hline- & + & - & $1: 640$ \\
\hline- & + & + & $1: 640$ \\
\hline+ & + & + & 0 \\
\hline
\end{tabular}

titer was abolished by absorption of the antiserum with soluble hog IF. Absorption of the antiserum with five other hog pyloric preparations which were effective in promoting the absorption of $\mathrm{Co}^{58}$-vitamin $\mathrm{B}_{12}$ in nonrefractory patients, in doses of 0.5 to $25 \mathrm{mg}$, abolished this residual titer. One hog gastric preparation, which was devoid of intrinsic-factor activity, did not abolish this titer. The titer which persisted after absorption with hog muscle or erythrocytes, and which subsequently was absorbed only by hog pyloric extracts possessing intrinsic-factor activity, was considered as probably representing antibodies to hog intrinsic factor.

Human serum studies. The sera of six patients who had become resistant to oral therapy while receiving a hog IF preparation were tested by this technique. The titer of the antibodies found,

TABLE III

Refractory patients; antibody titers and urinary excretion of $\mathrm{Co}^{58}$-vitamin $B_{12}$ (per cent of oral dose) *

\begin{tabular}{clrrr}
\hline \hline & & \multicolumn{3}{c}{ Schilling test } \\
\cline { 3 - 5 } & & \multicolumn{3}{c}{$\begin{array}{c}\text { Intrinsic factor administered } \\
\text { with vitamin } B_{12}\end{array}$} \\
\cline { 3 - 5 } Patient & Titer & None & Hog IF & NHGJ \\
\hline LW & $1: 100$ & 1.9 & $<0.1$ & 14.6 \\
WS & $1: 16$ & $<0.1$ & 0.2 & 11.1 \\
PC & $1: 4$ & 1.4 & $<0.1$ & $\dagger$ \\
HT & $1: 2$ & $<0.1$ & 0.5 & 16.0 \\
FC & $1: 2$ & 2.1 & 4.7 & 21.2 \\
SS & 0 & $<0.1$ & 4.3 & 13.5 \\
\end{tabular}

* The data shown correlate the in vitro titer of hemagglutinating antibodies with the results of Schilling tests in six refractory patients. The excretion values represent the $\%$ dose of $\mathrm{Co}^{58}$-vitamin $\mathrm{B}_{12}$ excreted in the urine when the $\mathrm{B}_{12}$ was administered alone, with hog pyloric extract (hog IF) and with $40 \mathrm{ml}$ of neutralized normal human gastric juice (NHGJ).

t At inception of therapy, patient responded optimally to oral vitamin $B_{12}$ and hog IF. 
together with results of Schilling tests, are shown in Table III. The titers described represent the titer of hemagglutination that could be abolished by prior absorption of the serum with hog IF. Antibodies were present in five patients but at a high titer in only one. The immunologic properties of the antibodies found in the serum of the patients with a titer of $1: 100$ are summarized in Figure 3. Other sera gave the same pattern of immunologic properties. The antibodies were neutralized by the addition of soluble hog IF (Figure 3 ) but were not affected by absorption with soluble hog muscle extract or with normal human gastric juice. In each hemagglutination experiment, antibodies were sought in serum obtained from patients with pernicious anemia who had not become refractory to oral medication, or who had been treated only with injections of vitamin $\mathrm{B}_{12}$. Sera from 20 such patients were tested. No hemagglutinating antibodies were found in any of these sera, nor was any detected in sera obtained from 10 normal subjects.

Other immunologic procedures. During electrophoresis of a mixture of normal rabbit serum

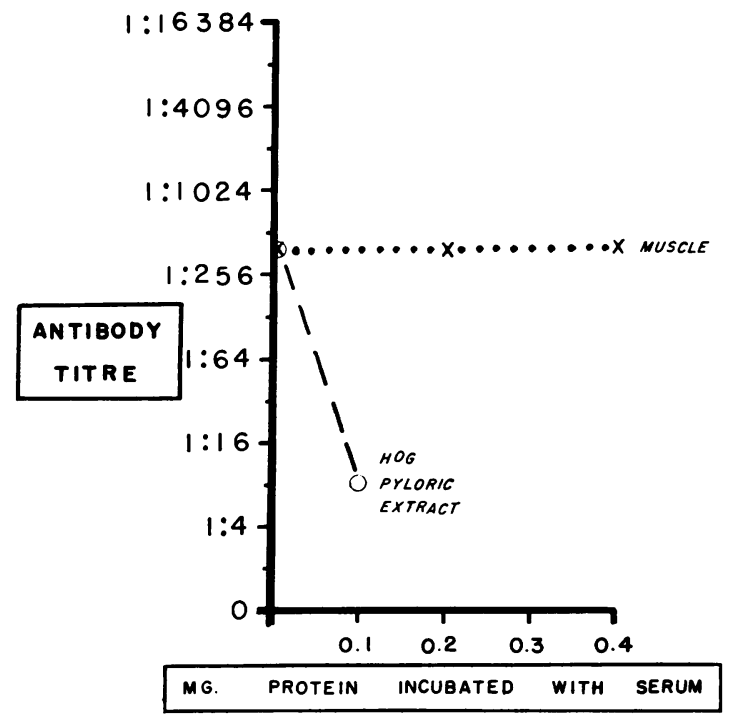

Fig. 3. The efFect on the hemagglutination titer OF PRIOR ABSORPTION OF HUMAN SERUM WITH HOG IF AND HOG MUSCLE EXTRACT. As shown here, high concentrations of human serum occasionally caused agglutination of the coated erythrocytes, which could not be prevented by absorption of the serum with hog pyloric extract. As described in the text, the antibody titer was defined as the titer of hemagglutination that could be prevented by absorption of the serum with hog IF.

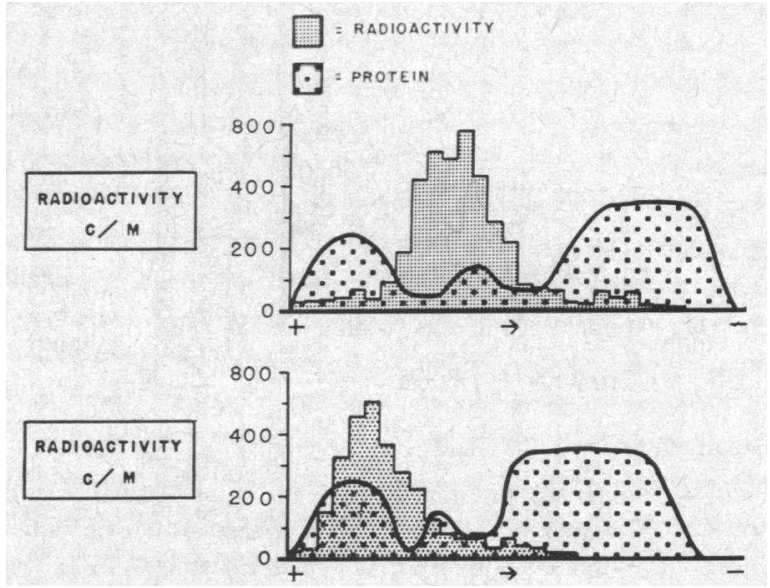

Fig. 4. PAPER ELECTROPHORESIS OF HOG IF WITH NORMAL AND IMMUNE RABBIT SERUM. $\mathrm{Co}^{58}$-vitamin $\mathrm{B}_{12}$ bound to hog IF migrated with the $\beta$-globulins of normal rabbit serum (upper); with immune serum, it migrated with the $\gamma$-globulin (lower).

and hog IF, the vitamin $\mathrm{B}_{12}$-binding protein migrated with the $\beta$-globulins (Figure 4 ). With immune rabbit serum, the $B_{12}$-binding peak migrated with the $\gamma$-globulins. This suggests that the immune rabbit sera contained antibodies that combined with the intrinsic-factor portion of the hog mucosal extract. This effect was noted also after the antiserum had been absorbed with hog muscle.

When serum from immunized rabbits was mixed with a hog pyloric extract in saline, optimal precipitation occurred at a dilution of $1: 2$. All of the radioactive vitamin $B_{12}$ added was recovered in the supernatant, suggesting that the $\mathrm{B}_{12}$-binding fraction of the pyloric extract was not involved in the precipitation reaction.

The results of Schilling tests performed on nonrefractory patients with classical pernicious anemia are summarized in Figure 5 and Table IV. These patients were fed rabbit serum and human serum, both normal and immune, together with $\mathrm{Co}^{58}$-vitamin $\mathrm{B}_{12}$ and hog IF in various combinations. A rough correlation appears to be present between titers of antibodies present in the human sera and degree of inhibition of absorption of radioactive vitamin $B_{12}$ in the presence of hog IF (Figure 5). A similar rough correlation appears to exist between in vivo activity of the rabbit antisera and in vitro titer after absorption with hog muscle extract (Table IV). The unabsorbed 


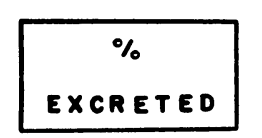

HUMAN TITRE
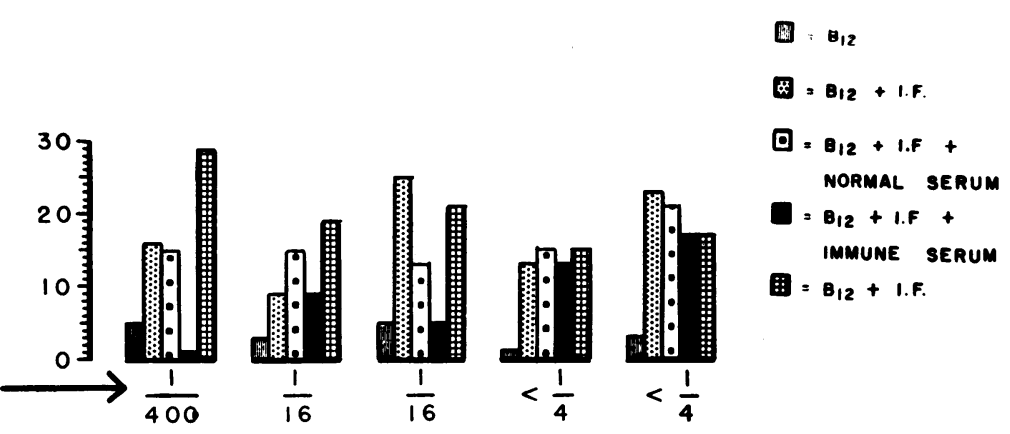

Fig. 5. Vitamin $B_{12}$ absorption (Schilling) tests in pernicious anemia patients: EFFECT OF MIXING NORMAL AND "IMMUNE" HUMAN SERUM WITH HOG IF. Each set of bars represents studies on one nonrefractory patient. Figures beneath the diagrams indicate the titer of antibodies in the immune serum.

titers of rabbit antiserum did not correlate with this in vivo activity.

An attempt was made to overcome the refractory state, by the technique described by Schwartz and co-workers (4). A large quantity of hog IF $(1,000 \mathrm{mg})$ was administered to one refractory patient (HT). This resulted in the urinary excretion in 48 hours of 5.6 per cent of the administered radioactivity (Schilling test). Three days later this patient excreted only 0.3 per cent of the radioactivity when the $\mathrm{B}_{12}$ was administered with $100 \mathrm{mg}$ of the hog IF preparation. This suggests that the inhibition of $\mathrm{B}_{12}$ absorption was overcome partially by an excess of hog IF but that this did not permit the efficient action of a smaller quantity of hog IF 3 days later.

\section{TABLE IV}

Sequential Schilling tests in one nonrefractory patient; hog $I F$ and Co ${ }^{58}$-vitamin $B_{12}$ were administered together with different rabbit antisera *

\begin{tabular}{cccc}
\hline & \multicolumn{3}{c}{ Rabbit antiserum } \\
\cline { 2 - 3 } $\begin{array}{c}\text { Schilling test } \\
\text { 48-Hour } \\
\text { excretion }\end{array}$ & Rabbit & $\begin{array}{c}\text { Total } \\
\text { titer }\end{array}$ & $\begin{array}{c}\text { Titer after } \\
\text { absorption } \\
\text { with hog muscle }\end{array}$ \\
\hline$\%$ & no. & & \\
16.2 & none & $1: 480$ & $1: 120$ \\
10.1 & I & $1: 480$ & $1: 60$ \\
15.6 & II & $1: 120$ & $1: 45 \dagger$ \\
17.0 & III & $1: 960$ & $1: 120$ \\
9.0 & IV & & \\
22.2 & none & & \\
\hline
\end{tabular}

* The hemagglutination determinations were performed on two different occasions, and both determinations gave similar results. Titers were determined by performing halving dilutions on 1:30 dilutions of serum, with and without prior absorption with soluble hog muscle extract.

† Partial agglutination at 1:30; complete agglutination at $1: 60$.
Thus, the antibodies detected in the sera of the immunized rabbits were partially absorbed by hog erythrocytes or hog muscle protein, but were completely neutralized only by hog pyloric extracts possessing intrinsic-factor activity. These antibodies combined with the vitamin $\mathrm{B}_{12}$-binding portion of a hog pyloric extract and altered its electrophoretic mobility. The antibodies detected in the sera of five of six patients who were refractory to hog pyloric material were not absorbed by nongastric hog protein or by human gastric juice, but only by hog preparations with intrinsic-factor activity. Sera obtained from nonrefractory patients with pernicious anemia and from normal subjects did not contain such antibodies.

\section{DISCUSSION}

The ingestion of partially purified hog pyloric extracts over a prolonged period elicits antibody formation in some subjects. As described in a preliminary report of these studies (13), the antibodies appear to combine with the intrinsic-factor portion of hog pyloric material to render the hog preparations ineffective in promoting vitamin $B_{12}$ absorption. Unlike the antibodies described by others, they do not react with human gastric juice, and this material promotes absorption of vitamin $\mathrm{B}_{12}$ in refractory patients.

The precipitins which appear in the sera of rabbits immunized with hog pyloric mucosal extracts appear to precipitate proteins other than those that bind vitamin $B_{12}$; i.e., intrinsic factor. This may explain the irregular correlation between precipitin titers and in vivo activity found by Taylor and Morton (14). 
Schwartz and colleagues (4) have postulated hog intrinsic factor-neutralizing antibodies in the sera of refractory patients, because they absorb vitamin $B_{12}$ mixed with human and rat gastric juice, and with massive doses of hog intrinsic factor, but do not absorb $B_{12}$ with wild-boar gastric juice or with small doses of hog intrinsic factor. They have also demonstrated that serum from such refractory patients appears partially to neutralize the activity of hog IF concentrates and human intrinsic-factor preparations when fed, together with such substances, to nonrefractory patients. This test for intrinsic factor-neutralizing substances in the serum is crude, and the results do not always correlate with the refractory state (4-6). Our data suggest that the hemagglutinating antibodies described probably are associated with the refractory state.

Antibody formation to hog intrinsic factor requires penetration of the intact intrinsic-factor protein into the body. Antibody stimulation by orally administered nonliving antigens has been reported $(15,16)$. In human serum, the absence of antibodies that could be absorbed with nongastric hog protein suggests that it is only the intrinsic-factor portion of the extract that enters the body. The absence of a demonstrable titer of antibodies in the serum of one refractory patient may imply that the antibody is present only in the mucosal cells, or that the circulating antibody titer was too low to be demonstrated by the present technique.

The demonstration by Schwartz and co-workers (4), that the refractory state is uncommon in patients receiving crude preparations of hog pylorus, may be explained by a less ready penetration of the intestinal mucosa by intrinsic factor in the presence of large quantities of other proteins. Another explanation would be to postulate the breakdown of a macromolecule of intrinsic factor into smaller active units which may more rapidly be absorbed intact from the gastrointestinal tract.

Glass, Stephanson, Rich and Laughton (17) have suggested that intrinsic factor may be a small molecule, bound to a larger molecule. In the purification procedures, the bond between the intrinsic factor and its carrier might be weakened, and one or the other molecule might be more readily absorbed into the body to stimulate anti- body formation. If this were true, then antibodies against either the intrinsic factor or the carrier protein might inhibit vitamin $3_{12}$ absorption.

The observation that patients treated with crude hog preparations absorb vitamin $B_{12}$, but usually do not develop antibodies to hog intrinsic factor, suggests that the intrinsic factor does not penetrate the intestinal mucosa in these subjects. This indicates that the vitamin $B_{12}$ absorbed is not necessarily accompanied by an immunologically active portion of the intrinsic factor.

\section{SUM MARY}

Antibodies that will react with hog pyloric mucosal extracts have been demonstrated by means of a hemagglutination technique. These antibodies do not react with normal human gastric juice, hog erythrocytes, or hog muscle protein. They have been found in sera obtained from rabbits immunized with an extract of hog pyloric mucosa, and in sera from certain patients with pernicious anemia who had become resistant to oral therapy with hog gastric extracts, but they have not been found in nonrefractory patients or in normal subjects.

Human and rabbit sera containing these antibodies, when mixed with hog IF and vitamin $B_{12}$ and fed to nonrefractory patients with pernicious anemia, inhibited the absorption of vitamin $B_{12}$ to a degree approximately proportional to the in vitro antibody titer.

The properties of these antibodies are consistent with the hypothesis that they may be responsible for acquired resistance to oral therapy with hog gastric material in pernicious anemia.

\section{REFERENCES}

1. Blackburn, E. K., Cohen, H., and Wilson, G. M. Oral treatment of pernicious anaemia with a combined vitamin $B_{12}$ and intrinsic factor preparation. Brit. med. J. 1955, 2, 460.

2. Schwartz, M., Lous, P., and Meulengracht, E. Reduced effect of heterologous intrinsic factor after prolonged oral treatment in pernicious anaemia. Lancet 1957, 1, 751.

3. Lowenstein, L., Brunton, L., Shapiro, L., de Leeuw, N., and Dufresne, M. Maintenance therapy of pernicious anaemia with oral administration of intrinsic factor and vitamin $\mathrm{B}_{12}$. Canad. med. Ass. J. 1957, 77, 923. 
4. Schwartz, M., Lous, P., and Meulengracht, E. Absorption of vitamin $B_{12}$ in pernicious anaemia: Defective absorption induced by prolonged oral treatment. Lancet 1958, 2, 1200.

5. Schwartz, M. Intrinsic factor antibodies in sera from patients with pernicious anaemia. Lancet 1960, 2, 1263.

6. Taylor, K. B. Inhibition of intrinsic factor by pernicious anaemia sera. Lancet 1959, 2, 106.

7. Flood, C. A., and West, R. Some properties of Castle's intrinsic factor. Proc. Soc. exp. Biol. (N. Y.) 1936, 34, 542.

8. Gyenes, L., Rose, B., and Sehon, A. H. Isolation of antibodies on antigen-polystyrene conjugates. $\mathrm{Na}$ ture (Lond.) 1958, 181, 1465.

9. Stavitsky, A. B., and Arquilla, E. R. Studies of proteins and antibodies by specific hemagglutination and hemolysis of protein-conjugated erythrocytes. Int. Arch. Allergy 1958, 13, 1.

10. McGarry, E., Sehon, A. H., and Rose, B. The isolation and electrophoretic characterization of the proteins in the urine of normal subjects. J. clin. Invest. 1955, 34, 832.

11. Grassmann, W., and Hannig, K. Ein quantitatives Verfahren zur Analyse der Serumproteine durch
Papierelektrophorese. Hoppe Seylers 7. physiol. Chem. 1952, 290, 1.

12. Boyd, W. C. Fundamentals of Immunology, 3rd erl. New York, Interscience, 1956.

13. Lowenstein, L., Cooper, B. A., Brunton, L., and Gartha, S. Antibodies in human and rabbit sera to hog intrinsic factor preparations (abstract). J. clin. Invest. 1959, 38, 1022.

14. Taylor, K. B., and Morton, J. A. An antibody to Castle's intrinsic factor. Lancet 1958, 1, 29.

15. The response of the antibody-forming apparatus to the administration of antigens otherwise than by injection into the tissues in Topley and Wilson's Principles of Bacteriology and Immunity, 4th ed., G. S. Wilson and A. A. Miles, Eds. London, Arnold, 1955, vol. 2, p. 1274.

16. Connolly, J. H., and Dick, G. W. A. Antibody response following intradermal or oral administration of formalinised poliomyelitis vaccine. Lancet 1958, 2, 333.

17. Glass, G. B. J., Stephanson, L., Rich, M., and Laughton, R. W. Intrinsic-factor activity of human gastric juice after fractionation by continuous electrophoresis on paper curtain. Brit. J. Haemat. 1957, 3, 401. 